\title{
Empowering the society through companies CSR agenda
}

\author{
Noor Adwa Sulaiman ${ }^{1, *}$, Rusnah Muhamad ${ }^{1}$ \\ ${ }^{1}$ Department of Accounting, Faculty of Business and Accounting, UM, Malaysia.
}

\begin{abstract}
Topic of socioeconomic issue is one of the most widely discussed globally as it gives effects to occupation, education, income, wealth, and place of residence of individuals. These social challenges should be addressed and resolved because to enhance individuals' contribution to economic and social life of their society and reduce social tensions and conflicts that negatively affects country's economic development. For this reason, in the Eleventh Malaysia Plan (2016-2020), the Malaysian Government stresses on the importance of participation of companies in empowering society to improve socioeconomic that could support equitable society. The empowerment programs aim to improve the education, quality of life and wellbeing of individuals and groups in society through reducing wealth gap, racial imbalance and promoting employment equity. One way to initiate greater involvement of the companies in socioeconomic development of the society is through CSR agenda. Specifically, the CSR agenda through empowerment activities (such as trainings programs, educational sponsorship mentorship program and learning and development programs) is believed to have a positive implication on society by way of improving wealth, education and skills of the individuals. Hence, this paper aims to develop measurement of empowerment in companies CSR agenda.
\end{abstract}

\section{Introduction}

One of the most significant discussions globally is on issue of socioeconomic inequality because it has effect on an individuals' economic activity including lack of education, poverty, wealth distribution, race discrimination and unemployment. Inequalities in socioeconomic can take place when individuals and groups in society may not have equal access

\footnotetext{
* Corresponding author: adwa@um.edu.my
} 
to rights, opportunities (e.g.: employment), or resources (e.g. healthcare, education). This exclusion may have prevented individuals and groups from participating in country's economic, social and political matters. Consequently, the government of Malaysia has identified inclusivity as one of key principle in achieving its national socio-economic development to achieve equitable society [1]. The principle focuses on the need for participation and commitment of all citizens to benefit economic growth and development of the country. Accordingly, in the $10^{\text {th }}$ Malaysia Plan, the government has emphasized about the importance of balance growth and equitable access to economic opportunities to all citizens regardless of gender, ethnicity, socio-economic status and geographic location [2]. Consequently, it should have resulted in a more inclusive society through poverty reduction, increased household income, reduction in income disparity, and improve quality of life. Nonetheless, income gaps for main ethnic groups remain large - per capita income for the ethnic Chinese and Indians were $64 \%$ and $27 \%$ higher than for the ethnic Malays [3]. Ownership of share capital among ethnic groups' (Malay, Chinese and Indian) remains disproportionate [4]. In addition, the $11^{\text {th }}$ Malaysia Plan (2015) reports distortion in wage structure - in 2014, 77\% of wage recipients received salaries of less than RM3,000 per month, inadequate skilled jobs in market, youth unemployment and low women participation in labour market.

For this reason, Malaysia has encouraged more active participation from companies to carry out empowerment programmes that could enhance greater access to education and skills training, infrastructure and employment opportunities for all segments of society [1]. Companies CSR agenda has a role to play in the empowerment of the society through activities that not only desirable in terms of the business objectives but also pursue development of society and satisfy social needs $[5,6]$. The companies' CSR agenda could empower individuals or groups of people by providing them with skills that they need and improve their sense of self confidence which effectively could reduce unequal education, income disparity and increase training opportunities, and more skilled categories of occupation. Despite numerous calls by government to encourage greater participation of private sector companies to conduct empowerment programmes in their CSR activities for development of society, evidence still shows that the situation has yet to improve [7]. CSR and empowerment has become an interdisciplinary area involving psychology, sociology, economic and business concepts with varying views of empowerment within the research areas, there is little consensus to the definition and the concept of empowerment. The lack of agreement among scholars concerning definition and concept of empowerment cause inconsistent and incommensurable empirical measures. For this reason, the main objective of this paper is to develop measurement constructs for empowerment in companies CSR agenda. It is hoped that this will encourage a better understanding of the significance of empowerment in CSR while providing recommendations for future research.

The rest of this paper continues as follows. Section 2 reviews relevant prior research that underlies the study. Section 3 outlines the research methodology. Sections 4 ascertain definition and measurement for empowerment through CSR agenda. Final section provides conclusion and recommendations of the study.

\section{Prior Research}

\subsection{Concepts of CSR}

Review of prior literature shows that research in CSR have covered various aspects such as CSR disclosures [8,9] and corporate governance [10, 11] and CSR and strategic 
management [12] as such, CSR has been studied in interdisciplinary area involving psychology, sociology, economic and business ideas. In addition, CSR is multifaceted concept and researchers have made several attempts to measure specific dimensions for it. In addition, for example, [13] proposes that CRS principles are makeup of two units: business and society that is interlinked with each other that can be measured in three dimensions. First dimension recognizes responsibilities of companies at three different levels (institutional, organizational and individual) and associated principles (principles of legitimacy, principles of public responsibility and principles of managerial discretion). Second dimension concerns with how the principles are related to action of companies that purposely examine issue of 'process of social responsiveness' that cover aspects of stakeholder management, environmental scanning and issues management. Third dimension looks at the outcomes of the companies' actions that can be analyzed through social policies, social programs and social impacts. Comparatively, [14] has divided CSR model into four key dimensions, namely economic, legal, ethical and philanthropic based on his earlier CSR model in year 1979 [14]. Later in year 2004, he proposes refined CSR model that focuses on responsibilities of companies, social issues that companies ought to address and social responsiveness or action of companies that are embedded in the areas of economic, social and legal to measure companies CSR [15]. In general, the model proposes these three domains as key facets of CSR and a number of measurements have been developed to measure CSR which is derived from Carroll's models. Generally, CSR is referring to business activities or practices of a company that is integrated with social, economic and environmental aspects that pursue social values and satisfy social needs of its various stakeholders $[16,17]$. In other words, CSR is concerned with outward expression of the company's value to its stakeholders: activities that a company demonstrates its focus other than company's bottom line- financial performance. That is to say those CSR activities are related to how business takes account of its economic, social and environmental impacts in the way it operates [18]. Overall, much of the discourse in concept of CSR in the literature is associated with analyzing companies' responsibilities and actions and effects of CSR on financial performance that fail to address social and developmental implications of CSR.

At the present time, discussion on CSR has also embraced issue of CSR role in society development [19-22]. Prior research suggests that contribution of CSR towards equality and equity of society can be achieved through four key components: redistribution, social protection, empowerment, and rights [19]. His proposed CSR framework considers how empowerment through companies CSR agenda is related to rights of the society with respect to issues such as minimizing disparities or leveling equity, enhancing equality of opportunity, correcting gross imbalances in the distribution of income, wealth and power and eventually social justice. Certainly the role of empowerment in CSR agenda by companies is important towards development of the society. Companies' participation in the economic and social life of the community has been somehow successful in reducing or eliminating inequities and inequalities [23]. There is an increase focus on the importance of empowerment in helping making people aware of and enabling to claim their fundamental rights [21]. It is crucial in achieving better community in terms of efficiency, growth, poverty reduction as well as attaining justice.

Various theoretical standpoints have been used in CSR research. In an analysis of the theoretical standpoints, [20] identifies research in CSR has employed utilitarian theory, managerial theory and relational theory to explain issues in CSR. This study utilizes relational theory to understand the CSR and empowerment. The relational theory is emphasized on various approaches in understanding CSR issues such as business and society stakeholders approach, corporate global citizenship and social contract theory. The social contract theory posits that, there is a social contract between the society and 
companies, which is an implicit social agreement that lays out the duties and rights of individuals or groups in the society on companies which they consider as a moral agent [22]. At the heart of the theory, society is recognized as legitimate stakeholder that companies are morally obligated to serve upon to legitimize its actions or behavior. The concept is closely related to stakeholder theory that explains about legitimacy of a claim on a firm. It describes that claim on a firm can be based upon a contract, exchange, legal title, legal right, moral right, at risk status, or moral interest in the harm and benefit generated by a firm's actions [24]. In this case, it is argued that companies are socially responsible towards socio-economic development of the society by considering them in companies' broader strategy In effect, companies are responsible to have proper motivation, method or manner of engaging with the society. Here, the concept of empowerment comes into play. Companies should be able to recognize fundamental human rights of the society to basic needs such as food, clean water, education, work, and health services [25]. Conceptually, empowerment is explained as a distinct approach for developing interventions and creating social change. It directs attention toward health, adaptation, competence, and natural helping systems [26]. From this aspect, empowerment is a process in which efforts are made by the individual or the society to exert control of their rights. The society, with the help of certain socially responsible companies, should be informed, trained and able to claim its rights under certain circumstances and events. The companies' CSR can leverage empowerment to enhance the society rights and stability, gain legitimacy and increase their accountability toward stakeholders [27]. Empowerment gives rights to different groups in the society to be included in the socio-economic development and thus increase equity and equality of policies [19].

\subsection{Concepts of Empowerment}

Empowerment is a multidimensional concept. Its definition commonly associated with economic, human and social empowerment, political and cultural empowerment. Economic empowerment is defined as the right of the society to have appropriate skills, capabilities and resources and access to secure and sustainable incomes and livelihoods [28]. As such, access to assets and resources would be the focus. The human and social empowerment has been defined as multidimensional of social process that helps people gain control over their own lives. This process would foster power in society, for use in their own lives, their communities and their society, by being able to act on issues that they define as important [29]. Social empowerment is about the process of developing a sense of autonomy and selfconfidence of individuals [30]. In comparison, [31] characterize political empowerment as the capacity to analyse, organize and mobilize. It refers to collective action that is needed for collective change for citizens to claims their rights and entitlements. Comparatively, cultural empowerment is about redefining rules and norms and the recreating of cultural and symbolic practices in the society [32]. This study would be focusing on concept of economic and social empowerment as a basis in developing conceptual model and measurement for empowerment in companies CSR agenda.

Research in empowerment has covered broad spectrum of groups that include employee, customer, supplier youth and women. As a result, concept of empowerment is diverse that bring different meaning for different authors. Accordingly, this study will only review concepts of empowerment from the economic and social aspects because it is aligned with the focus of the study. In all, prior studies have documented that employee empowerment has been one of the topic that has been extensively investigated. Two key dimensions have been identified in this aspect of empowerment. First, empowerment is connected to psychological construct that is manifested in four cognitions: meaning (fit between the job task and one's own beliefs, values, and behaviors); competence (belief in one's ability to 
perform a job well); self-determination (feeling like one has control over one's work); and impact (feeling one can affect one's work outcomes) [33, 34]. Scholars such as [35, 36] regard psychological empowerment as motivational construct that involve process of enhancing feelings of self-efficacy among individuals by way of enhancing skills and abilities to do his/her job effectively. The psychological empowerment is considered to be a cognitive state characterized by a sense of perceived control, perceptions of competence, and internalization of the goals and objectives of the organization. Second, construct of the empowerment is related to relational aspect that is perceived control (includes beliefs about authority, decision-making, latitude and availability of resources, autonomy in scheduling, etc), perceived competence (reflects role mastery that in addition to successful completion of assigned tasks also requires coping up with the non-routine tasks) and goal internalization (captures the energizing property of a worthy cause or exciting vision provided by the organization leadership) [34]. Similarly, the literature on economic empowerment is vast, and a large part of this focuses on the economic empowerment that centers around four broad areas: a) the promotion of the assets of people; b) transformative forms of social protection; c) microfinance; and d) skills training. Economic empowerment is concerned with providing equal rights, opportunities, asset ownership and responsibilities to individual that eventually improving equality [37].

Table 1. Prior Research-Measurement of Empowerment

\begin{tabular}{|c|c|c|}
\hline Author(s) and year & Construct(s) and items (s) & $\begin{array}{l}\text { Study design } \\
\text { research context }\end{array}$ \\
\hline Kosar \& Naqvi (2016) & $\begin{array}{l}\text { Meaning: } 3 \text { items } \\
\text { Competence: } 3 \text { items } \\
\text { Self-Determination: } 3 \text { items } \\
\text { Impact: } 3 \text { items }\end{array}$ & $\begin{array}{l}\text { Survey } \\
\text { Employee empowerment }\end{array}$ \\
\hline Kumar (2015) & $\begin{array}{l}\text { Meaning: } 3 \text { items } \\
\text { Competence: } 3 \text { items } \\
\text { Self-Determination: } 3 \text { items } \\
\text { Impact: } 3 \text { items }\end{array}$ & $\begin{array}{l}\text { Survey } \\
\text { Employee empowerment }\end{array}$ \\
\hline Ugwu et al (2013) & $\begin{array}{l}\text { Meaning: } 3 \text { items } \\
\text { Competence: } 3 \text { items } \\
\text { Self-Determination: } 3 \text { items } \\
\text { Impact: } 3 \text { items }\end{array}$ & $\begin{array}{l}\text { Survey } \\
\text { Employee empowerment }\end{array}$ \\
\hline $\begin{array}{l}\text { Dimitriades et al } \\
(2007)\end{array}$ & $\begin{array}{l}\text { Perceived competence: } 5 \\
\text { items } \\
\text { Goal internalization: } 5 \text { items } \\
\text { Perceived control: } 5 \text { items }\end{array}$ & $\begin{array}{l}\text { Survey } \\
\text { Employee empowerment }\end{array}$ \\
\hline Cyboran (2005) & $\begin{array}{l}\text { Meaning: } 1 \text { items } \\
\text { Competence: } 1 \text { items } \\
\text { Self-Determination: } 1 \text { items } \\
\text { Impact: } 1 \text { items }\end{array}$ & $\begin{array}{l}\text { Survey } \\
\text { Employee empowerment }\end{array}$ \\
\hline Hui et al (2004) & Self-determination: 3 items & $\begin{array}{l}\text { Survey } \\
\text { Employee and Customer } \\
\text { empowerment }\end{array}$ \\
\hline Hancer (2001) & $\begin{array}{l}\text { Meaning: } 3 \text { items } \\
\text { Competence (self-efficacy): } \\
3 \text { items } \\
\text { Influence: } 6 \text { items }\end{array}$ & $\begin{array}{l}\text { Survey } \\
\text { Employee empowerment }\end{array}$ \\
\hline
\end{tabular}




\begin{tabular}{|l|l|l|}
\hline Spreitzer (1995) & Meaning: 3 items & Survey \\
& Competence: 3 items & Employee empowerment \\
& $\begin{array}{l}\text { Self-Determination: } 3 \text { items } \\
\text { Impact: } 3 \text { items }\end{array}$ & \\
\hline
\end{tabular}

Study by [33] has elaborated and validated a multidimensional measure of psychological empowerment at the workplace. He identified four constructs with 12 items in measuring empowerment, which are meaning (fit between the job task and one's own beliefs, values, and behaviors); competence (belief in one's ability to perform a job well); self-determination (feeling like one has control over one's work); and impact (feeling one can affect one's work outcomes). His model of psychological empowerment was developed based on earlier studies by [35] [40]. Prior research has extensively used empowerment scale by (33) to measure empowerment. For example, [39] examines the impact of empowerment on service employees and found that psychological empowerment has positive influence on employee job satisfaction and loyalty to organization. Comparatively, [38] modified the scales done by [33] by adopting only three of the constructs which are meaning, competence (self-efficacy) and influence. This study investigates the reciprocal relationship between psychological empowerment and job satisfaction of restaurant workers. This study shows that psychological empowerment was positively and significantly related to job satisfaction. In addition, [41] in their study shows that there is higher employee satisfaction when they are empowered. In this study, empowerment was measured by [33] self-determination sub-scale using 3 sample of questions. This three-item subscale was designed to measure perceived autonomy at work.

Attempts to measure empowerment can be also seen through study done by [42] which examined the influences of reflection on the self-perception of empowerment in the workplace using four components of psychological empowerment. The empowerment approach used is again based on the Spreitzer's model which is based on the approach that empowerment is defined as increased intrinsic motivation manifested in four cognitions [40] namely: meaning, competence, self-determination and impact. This study provides sample questions for each components of empowerment. This measure describes the extent to which employees believe they are empowered in their jobs. On the other hand, [43] contributes to the stream of research on empowerment by investigating the construct of psychological empowerment among public employees. Psychological empowerment was measured with a 15-item scale developed by [34], for the exact wording of the items and tapping the three dimensions of perceived competence, goal internalization and perceived control. This author applied the concept of empowerment as the employee-experienced power. According to him, review of the major approaches to the experience of power in conjunction with the various streams of empowerment research described in prior studies reveals that, at on individual level, the three main dimensions of the experience of power underlying empowerment process are: a) power as perceived control, b) power as perceived competence, and c) power as being energized toward achieving valued goals. The study done by [43] followed fairly closely the empowerment measurement that in the [34] study.

Prior research has employed Spreitzer's measurement scale to examine the effect of psychological empowerment. For example, [44] examine the association between psychological empowerment and behavioral outcomes of employee. In their study, they found out that psychological empowerment has positive significant relationship with the employee engagement. The same scale was also used by [45] in his study to measure relationship between empowerment and leadership experience and education. Other example of study was done by [46] show the moderating role of psychological empowerment on trust and employee engagement. In another study, [47] investigating the effects of psychological empowerment dimensions of job satisfaction. Other studies have 
also adopted empowerment measurement scale by Spreitzer to measure psychological empowerment [48-53].

Based on preceding research stated above, it can be concluded that Spreitzer's measurement scale has been widely adapted in measuring psychological empowerment [33]. Although a variety of approaches have been taken by different authors, and many of the studies are evolvements of previous studies, it is evidenced that Spreitzer's measurement scale appear to be at the forefront of most research in this literature [33]. Table I provides an overview of selected prior research to highlight the numerous measures and method applied in various context.

Overall, the concept of empowerment is diverse. In general, it focused on management practices or activities that are designed to "empower" various stakeholders through access to information and resources and enhance autonomy, responsibility and participation of the various groups in the society thus greater equality and equity of in the society can be achieved. Thus, empowerment in this study is defined as practices or activities that carry out by companies that provide opportunities, resources, knowledge and skills, and motivation to allow individuals to gain authority and ability to improve their competence and enhance their satisfaction and self-efficacy. Society can be empowered through knowledge and skills by giving adequate access to resources, knowledge and skills. This study proposes assessment scale to measure impact of empowerment to equitable society.

\section{Research Methodology}

A quantitative approach is adopted in this paper whereby relevant literature and documents have extensively been reviewed. The purpose of the review is to ascertain definitions and concepts of empowerment as well as to establish appropriate items to measure empowerment within the context of CSR. There are several types of literatures and documents that have been reviewed which includes academic journals, books, reports, etc. This study uses medium for the literature search such as ABI/INFORMS Proquest, Emerald and Google Scholar so that a pool of studies for the review purposes can be obtained. The literature search has focused on the concept of empowerment with related to CSR activities. Previous studies on empowerment, CSR, and equitable society are extensively been reviewed in this paper in order to identify the themes and frequent issues in this area. The important key terms regarding empowerment such as meaning, concept, dimensions, construct, measurement, as well as questionnaires have been widely used throughout the search. This paper has reviewed related literatures to propose definition of empowerment within the context CSR. Research framework was established to coincide the concept of empowerment and CSR activities so that it will be much easier to generate the items. Related sample of questionnaires from past researchers were used as a reference to measure the dimension of empowerment and the relevancy to CSR agenda.

\section{Measuring Concepts of Empowerment through CSR Agenda}

Literature recognized the important role of companies in the society. Essentially, on the important contribution of companies CSR agenda toward socioeconomic development of the society [19]. The empowerment dimension of CSR of companies is about giving rights and opportunities to the individuals or groups in the society on occupation, education, income and wealth that promote social inclusion and equitable society. The measurement items for empowerment through CSR agenda by companies were adapted from [33, 43]. 
The proposed measurement items also took into consideration study and report by [28] and [30] on conceptualization of empowerment. Based on the literature review the empowerment measurement items consist of 45 items that were further scrutinize based on argument from the literature. As a result, only 15 of the total 45 items were chosen for use in this study. The 15 items measure the three dimensions are Perceived competence, Goal internalization, and Perceived control in the context of CSR initiatives by companies in their effort to achieve equitable society through socioeconomic equality. The list of items is shown in Table II.

Table II: Proposed Definition and Attributes of the Study

\begin{tabular}{|l|l|}
\hline $\begin{array}{l}\text { Empowerment refers to practices or activities that carry out by companies that provide } \\
\text { opportunities, resources, knowledge and skills, and motivation to allow individuals to } \\
\text { gain authority and ability to improve their competence, confidence and enhance their } \\
\text { self-efficacy. }\end{array}$ \\
\hline \multicolumn{1}{|c|}{ Attributes of the Study } \\
\hline \multicolumn{2}{|c|}{ Perceived Control } \\
\hline 1 & $\begin{array}{l}\text { Companies should provide individual with relevant trainings programs and } \\
\text { workshops to improve individual's knowledge and skills. }\end{array}$ \\
\hline 2 & $\begin{array}{l}\text { Companies should have awareness programs to improve the individual } \\
\text { knowledge on products and the organization. }\end{array}$ \\
\hline 3 & $\begin{array}{l}\text { Companies should provide mode of communication (e.g. direct engagement, } \\
\text { proxy voting and social reporting) that allow the individual to participate in } \\
\text { organizational decision making process. }\end{array}$ \\
\hline 4 & $\begin{array}{l}\text { Companies should provide educational sponsorship to elevate the standard of } \\
\text { education of the individual. }\end{array}$ \\
\hline 5 & $\begin{array}{l}\text { Companies should provide financial aid to underprivileged individual to elevate } \\
\text { their standard of living. }\end{array}$ \\
\hline 6 & $\begin{array}{l}\text { Companies should provide their employee with volunteerism program with the } \\
\text { community to boost employees' motivation and social skills. }\end{array}$ \\
\hline 7 & $\begin{array}{l}\text { Companies should provide mentorship program to nurture individual talents' } \\
\text { professional and personal development. }\end{array}$ \\
\hline 8 & $\begin{array}{l}\text { Companies should provide learning and development programs via internships } \\
\text { to ensuring that individual are able to fulfill their potential. }\end{array}$ \\
\hline & \multicolumn{2}{|c|}{ Perceived Competence } \\
\hline 10. & $\begin{array}{l}\text { Companies should assist individual in achieving necessary capabilities that are } \\
\text { required to do job well. }\end{array}$ \\
\hline 10. & $\begin{array}{l}\text { Companies should assist individual in achieving the skills and abilities to do job } \\
\text { well. }\end{array}$ \\
\hline 11. & Companies should assist individual to be competence to work effectively. \\
\hline 13. & Companies should assist individual to work efficiently. \\
\hline 14 & Companies should assist individual to handle the challenges at work. \\
\hline 15. & $\begin{array}{l}\text { Companies can inspire individual to be enthusiastic about his or her contribution } \\
\text { to the organization. }\end{array}$ \\
\hline
\end{tabular}

\section{Conclusion and Recommendation}


This paper has attempted to extend the knowledge on empowerment within CSR domain by critically examining the definitions, concepts and measures of empowerment as relevant for the CSR agenda. The review of the literature reveals that the scope of the conceptualization of empowerment within companies CSR agenda could be discussed within psychological perspective of the individuals in the society. In the future, empirical data can be collected through questionnaires in order to test the validity of the instruments.

\section{Acknowledgements}

We would like to acknowledge the financial support provided by University of Malaya under the Equitable Society Research Cluster (ESRC) research grant RP018C-13SBS.

\section{References}

1. E. P. U, $11^{\text {th }}$ Malaysia Plan (2016-2020) (Economic Planning Unit, Prime Minister's Department, 2015)

2. E. P. U, $10^{\text {th }}$ Malaysia Plan 2011-2015 (Economic Planning Unit, Prime Minister's Department, 2010)

3. M. Y. Saari, E. Dietzenbacher, \& B. Los., Sources of Income Growth and Inequality across Ethnic Groups in Malaysia, 1970-2000, (World Development, 2015)

4. Department of Statistics Malaysia \& Companies Comission of Malaysia 2016

5. H.R. Bowen, Social Responsibilities of the Businessman (Harper and Row, NY, 1953)

6. R. Jatana, \& D. Crowther, Soc. Resp. J., 3, 40-48 (2007)

7. N. N. Nik Ahmad \& M. Sulaiman, Int. J. of Com. \& Mngmt., 14, 44-58 (2004)

8. M. C. Chan, J. Watson, D. Woodliff, J. of Bus. Ethics, 125, 59-73 (2014)

9. T. Shavit \& A. M. Adam, A Preliminary Exploration of the Effects of Rational Factors and Behavioral Biases on The Managerial Choice to Invest in Corporate Responsibility (Managerial and Decision Economics, 2011)

10. G. Giannarakis, Int. J. of Law \& Mngmt., 56, 393 (2014)

11. M. A. Harjoto, H. Jo, J. of Bus. Ethics, 100, 45-67 (2011)

12. O. Flak \& A. Pyszka, The Impact of Corporate Social Responsibility (CSR) On Companies' Competitiveness - Proposed Research Directions (Equilibrium, 2011)

13. D. Wood, Corporate Social Responsiveness Revisited (Academy of Management Review, 1991)

14. A. B. Carroll, A Three-Dimensional Conceptual Model of Corporate Performance (Academy of

Management Review, 1979)

15. M. Schwartz, \& A. Carroll, Corporate Social Responsibility: A Three-Domain Approach (Business Ethics Quarterly, 2003).

16. D. R. Lichtenstein, M. E. Drumwright, B. M. Braig, J. of Marketing, 68, 16-32 (2004)

17. C. B. Suresh \& P. Sudeepta, J. of Transnational Mngmt., 16, 20-35 (2011).

18. C. Nwaneri, Int. J. of Bus and Mngmt, 10, 60. (2015)

19. P. Utting CSR And Equality (Third World Quarterly, 2007) 
20. M. Ismail, The J. of Int. Res., 2, 199-209 (2009)

21. S. Mena, M. de Leede, D. Baumann, N. Black, S. Lindeman, L. Mcshane, J. of Bus. Ethics,93, 161-188 (2009)

22. A. Amran, M. M. Zain, M. Sulaiman, T. Sarker, S K. Ooi, Empowering Society for Better Corporate Social Responsibility (CSR): The Case of Malaysia (Kajian Malaysia, 2013)

23. J. Hayes, E. Hannold, J. of Health and Human Serv. Administration, 30, 352-77 (2007)

24. R. Mitchell, B. Agle, D. Wood, Towards a Theory of Stakeholder Identification and Salience: Defining the Principle of Who and What Really Counts (The Academy of Management Review, 1997)

25. International Covenant on Economic Social and Cultural Rights (2002)

26. M. A. Zimmerman, American J. of Community Psy., 23, 81-99 (1995)

27. N. D. Çakar \& A. Ertürk, J. of Small Bus. Mngmt., 48, 325-359 (2010)

28. C. Luttrell, S. Quiroz, C. Scrutton, K. Bird, Understanding and Operationalising Empowerment (London: Overseas Development Institute, 2009)

29. N. Page, \& C. E. Czuba, J. of Ext., 37, 24-32 (1999)

30. http://www.gsdrc.org/topic-guides/voice-empowerment-andaccountability/supplements/social-and-economic-empowerment

31. L. H. Piron, \& F. Watkins, DFID Human Rights Review: A Review of How DFID Has Integrated Human Rights Into Its Work. (DFID, 2004)

32. N. P. Stromquist, The Theoretical and Practical Bases for Empowerment in: Women's Education and Empowerment (Report of International Seminar, 1993)

33. G. M. Spreitzer, Academy of Mngmt. J., 38, 1442-6 (1995),

34. S. Menon, Employee Empowerment: An Integrative Psychological Approach (Applied Psychology: An International Review, 2001)

35. J. A. Conger, \& R. N. Kanungo, The Empowerment Process: Integrating Theory and Practice (Academy of Management Review, 1988)

36. K. Y. H. Fock, The empowerment of service workers: Conceptualization and impacts across cultures (The Chinese University of Hong Kong, H. K., 2004)

37. T. Aind \& S. Oraon, Economic empowerment of tribal women in Jharkhand, an analysis. Anusandhanika, 5(1), 85-92. (2013)

38. M. Hancer, An analysis of psychological empowerment and job satisfaction for restaurant employees (Order No. 3011067). Available from ABI/INFORM Collection. (2001)

39. M. D. Fulford \& C. A. Enz, J. of Managerial Issues. 7, 161-175 (1995)

40. K. W. Thomas \& B. A. Velthouse, Cognitive Elements of Empowerment: An Interpretive Model Of

Intrinsic Task Motivation (Academy of Management Review, 1990)

41. M. K. Hui, K. Au, H. Fock, J. of Int. Bus. Studies, 35, 46-60 (2004)

42. V. L. Cyboran, V. L. The influence of reflection on employee psychological empowerment: Report of an exploratory workplace field study (Performance Improvement Quarterly, 2005)

43. Z. S. Dimitriades, \& T. Maroudas, Internal service climate and psychological empowerment among public employees (Transforming Government: People, Process and Policy, 2007) 
44. R. Kosar, \& S. M. M. R. Naqvi, S. M. M. R. Psychological Empowerment and Employee Behaviors Employee Engagement as Mediator and Leader-Member Exchange as Moderator. (Economic and Social Development: Book of Proceedings, 2016).

45. S. Solansky, Ldship \& Org. Dvlpmnt J., 7, 637. (2014)

46. F. O. Ugwu, I. E. Onyishi, \& A.,M. Rodríguez-Sánchez, Personnel Review, 3, 377-400. (2014)

47. K. M. Kumar, \& R. Moorthy, J. of Contemporary Res in Mngmnt, 1, 1. (2015)

48. H. Luoh, S. Tsaur, \& Y. Tang, Int.J. of Cntmpry Hsptlty Mngmnt, 7, 1100-1117. (2014)

49. S. Jha, J. of Mngmnt Res, 2, 105-117. (2013)

50. L. Lin, \& C. Tseng, Int. J. of Orgztnal. Innov. 4, 21-29. (2013)

51. C.C Schermuly, R. A. Schermuly, \& B. The Int. J. of Eductnal. Mngmnt, 3, 252264. (2011)

52. P. Gkorezis, L., Hatzithomas, \& E. Petridou, J. of Mng. Issues, 1, 83-95, 7-8. (2011)

53. F. Wei, X. Yuan, \& Y. Di, Effects of transactional leadership, psychological empowerment and empowerment climate on creative performance of subordinates: A cross-level study (Frontiers of Business Research in China, 2010) 